CASE REPORT

\title{
Prepubertal gynecomastia in Peutz-Jeghers syndrome: incomplete penetrance in a familial case and management with an aromatase inhibitor
}

\author{
Hervé Lefevre, Claire Bouvattier, Najiba Lahlou ${ }^{1}$, Catherine Adamsbaum ${ }^{2}$, Pierre Bougnères and Jean-Claude Carel \\ Department of Pediatric Endocrinology and INSERM U561, Groupe Hospitalier Cochin -Saint Vincent de Paul and Université Paris V, 82 av Denfert \\ Rochereau, 75014 Paris, France, and ${ }^{1}$ Laboratory of Hormonal Biochemistry and ${ }^{2}$ Department of Radiology, Groupe Hospitalier Cochin-Saint Vincent de \\ Paul, 75014 Paris, France
}

(Correspondence should be addressed to J-C Carel; Email: carel@paris5.inserm.fr)

\begin{abstract}
Background: Peutz-Jeghers syndrome (PJS) is a rare autosomal-dominant disorder characterized by multiple gastrointestinal hamartomatous polyps, mucocutaneous pigmentation and increased predisposition to various neoplasms. Endocrine manifestations in PJS include gynecomastia due to calcified Sertoli cell testicular tumors usually referred to as large-cell calcifying Sertoli cell tumors (LSCT).

Objective: To evaluate the value of endocrine markers and aromatase inhibitor treatment in children with PJS and LSCT.

Design and setting: Familial cases, followed in a tertiary care center.

Patients: Two male siblings aged 7 and 9 years with PJS and LSCT.

Intervention: Third generation aromatase inhibitor (anastrozole) in one of the patients.

Main outcome measures: Longitudinal measurements of sex-steroids, gonadotropins, Sertoli cell markers and auxological evaluation.

Results: The two male siblings with PJS had similar bilateral multifocal testicular calcifications and biochemical evidence of Sertoli cell dysfunction manifested by elevated plasma inhibin- $\alpha$ levels. Only one sibling had gynecomastia. Estradiol levels were normal in both. During treatment with anastrozole, estradiol levels, growth and skeletal maturation, as well as Sertoli cell markers (inhibin B, inhibin- $\alpha$ and anti-Mullerian hormone) decreased.

Conclusions: Inhibin- $\alpha$ may be considered as a marker for LSCT in children with PJS, pointing to a specific defect in inhibin regulation in this condition. Moreover, the decrease in Sertoli cell markers during aromatase inhibitor treatment suggests that increased estrogen production is a primary event regulating downstream production of Sertoli cell peptides. Anastrozole is efficient in controlling the clinical features of the disease and should be proposed as an alternative to bilateral orchidectomy, which is often performed in this condition.
\end{abstract}

European Journal of Endocrinology $154221-227$

\section{Introduction}

The Peutz-Jeghers syndrome (PJS) is a rare autosomal-dominant disorder classically characterized by the association of multiple gastrointestinal hamartomatous polyps, mucocutaneous pigmentation and increased predisposition to various neoplasms $(1,2)$. Inactivating germline mutations of the LKB1/STK11 gene, which encodes a serine/threonine kinase have been found in patients with PJS (3). Endocrine manifestations of PJS include gynecomastia due to estrogen production by calcified Sertoli cell testicular tumors, often bilateral and multifocal, usually referred to as large-cell calcifying Sertoli cell tumors (LSCT) $(4,5)$.

We report two male siblings with PJS and bilateral multifocal testicular calcifications. Although biochemical evidence of Sertoli cell dysfunction was similar in both patients, clinical expression was different and only one of them had gynecomastia. He was treated with an aromatase inhibitor to reduce skeletal maturation. Their father also had PJS, but no gynecomastia or testicular calcification, further emphasizing the phenotypic variability of the disease. 


\section{Patients and methods}

\section{Laboratory assays}

Radioimmunoassays were used to measure serum concentrations of testosterone (CisBio International, Gif-sur-Yvette, France), dehydroepiandrosterone sulfate (CisBio International), and estradiol (DiaSorin, Antony, France). The detection limit for plasma estradiol was $2 \mathrm{pg} / \mathrm{ml}$. Luteinizing hormone (LH) and follicle-stimulating hormone (FSH) were measured by time-resolved immunofluorometric assay (Delfia, Wallac, Turku, Finland). Inhibin B was measured by a solid phase sandwich assay (Serotec, Oxford, Oxon, UK). Anti-Mullerian hormone (AMH) was measured with a solid phase sandwich assay (DSL-France, Cergy-Pontoise, France). Details of the assays used and their precision profiles have been described previously $(6,7)$. Immunoreactive inhibin- $\alpha$ was measured by RIA using antiserum 1989 raised against purified $31 \mathrm{kDa}$ bovine inhibin, kindly donated by D M de Kretzer (Monash University, Clayton, Australia) (8). Purified bovine $31 \mathrm{kDa}$ inhibin iodinated by the lactoperoxidase method was used as a tracer. Diluted human follicular fluid was used as a standard. Its bioactivity was $280 \mathrm{U} / \mathrm{ml}$ as assessed by in vitro bioassay with dispersed rat pituitary cells. The sensitivity was $28 \mathrm{U} / \mathrm{l}$. Longitudinal assessment of hormonal values was performed in a single assay using stored frozen samples.

\section{DNA sequencing}

Exons 1 to 9 of LKB1/STK11 were directly sequenced after PCR amplification using an Applied Biosystems (Foster City, CA, USA) model 377 sequencer (9).

The subjects and their family gave informed consent for the study and were informed of the investigative nature of the treatment that was used in patient $\mathrm{IV}_{5}$.

\section{Case reports}

Patient $\mathrm{IV}_{5}$, a 7 -year-old male member of a family with PJS presented with progressive gynecomastia that had developed over the course of 2 years. Physical examination revealed a healthy boy with pigmented lesions of the lips and bilateral gynecomastia, $5 \mathrm{~cm}$ in diameter, corresponding to a female Tanner B3 stage (Fig. 1). His testicular volume was $4 \mathrm{ml}$ bilaterally. The penis was infantile and there was no pubic or axillary hair. Height was $134 \mathrm{~cm}$ (+3 standard deviation score
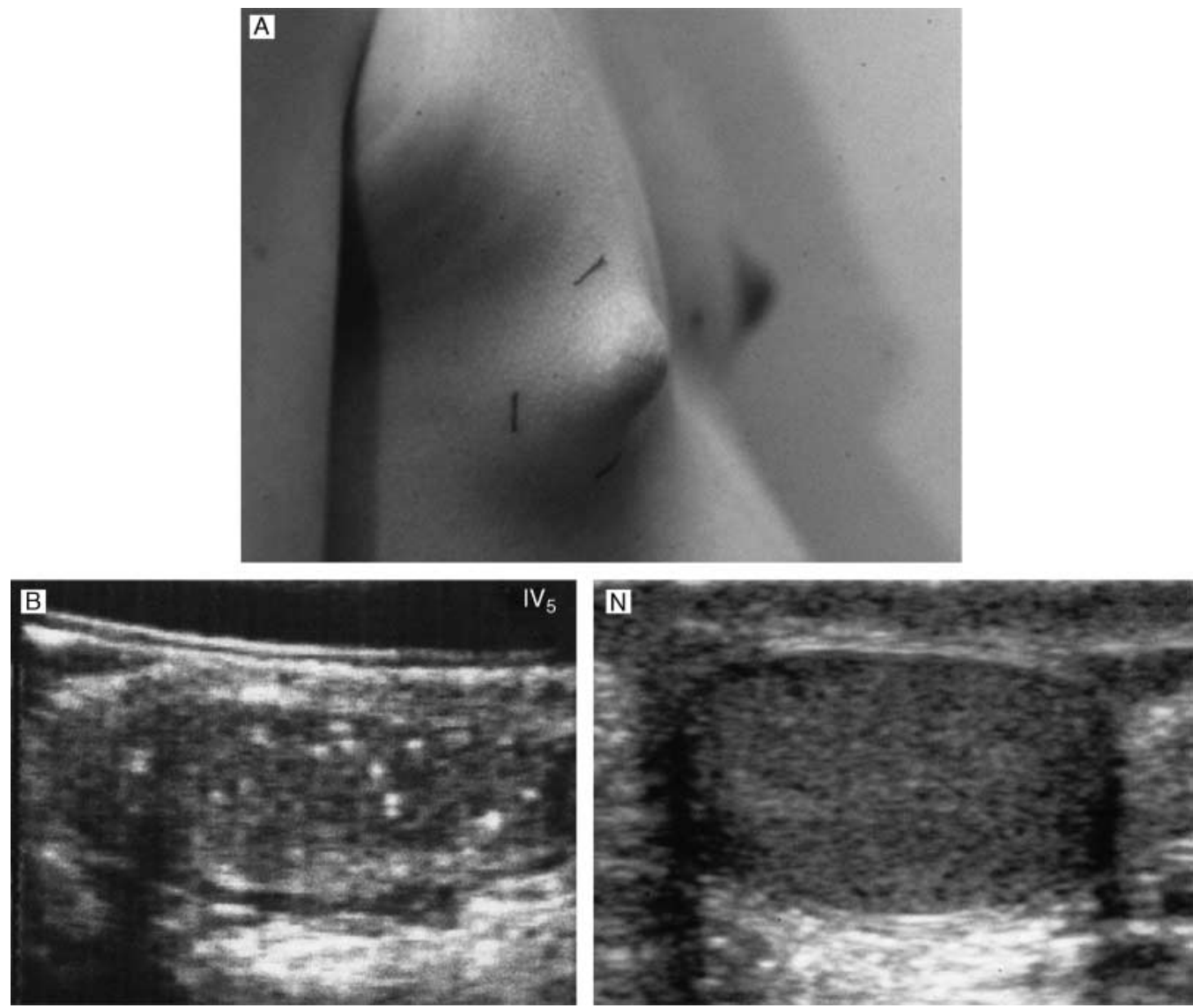

Figure 1 Gynecomastia $(\mathrm{A})$ and testicular calcifications on ultrasound $(\mathrm{B})$ in patient $\mathrm{IV}_{5}$ at initial evaluation at the age of 7 years. A normal testis from an age-matched individual is shown for comparison $(\mathrm{N})$. 
(SDS)), with a growth velocity of $9 \mathrm{~cm} /$ year $(+4 \mathrm{sDS}$ for age) and normal weight for height (Fig. 2). Target height was $179 \mathrm{~cm}(+1 \mathrm{sDS})$. Bone age was 10 years (10). There was no familial history of gynecomastia, in particular among family members with PJS (Fig. 3). An abdominal computed tomography scan to exclude
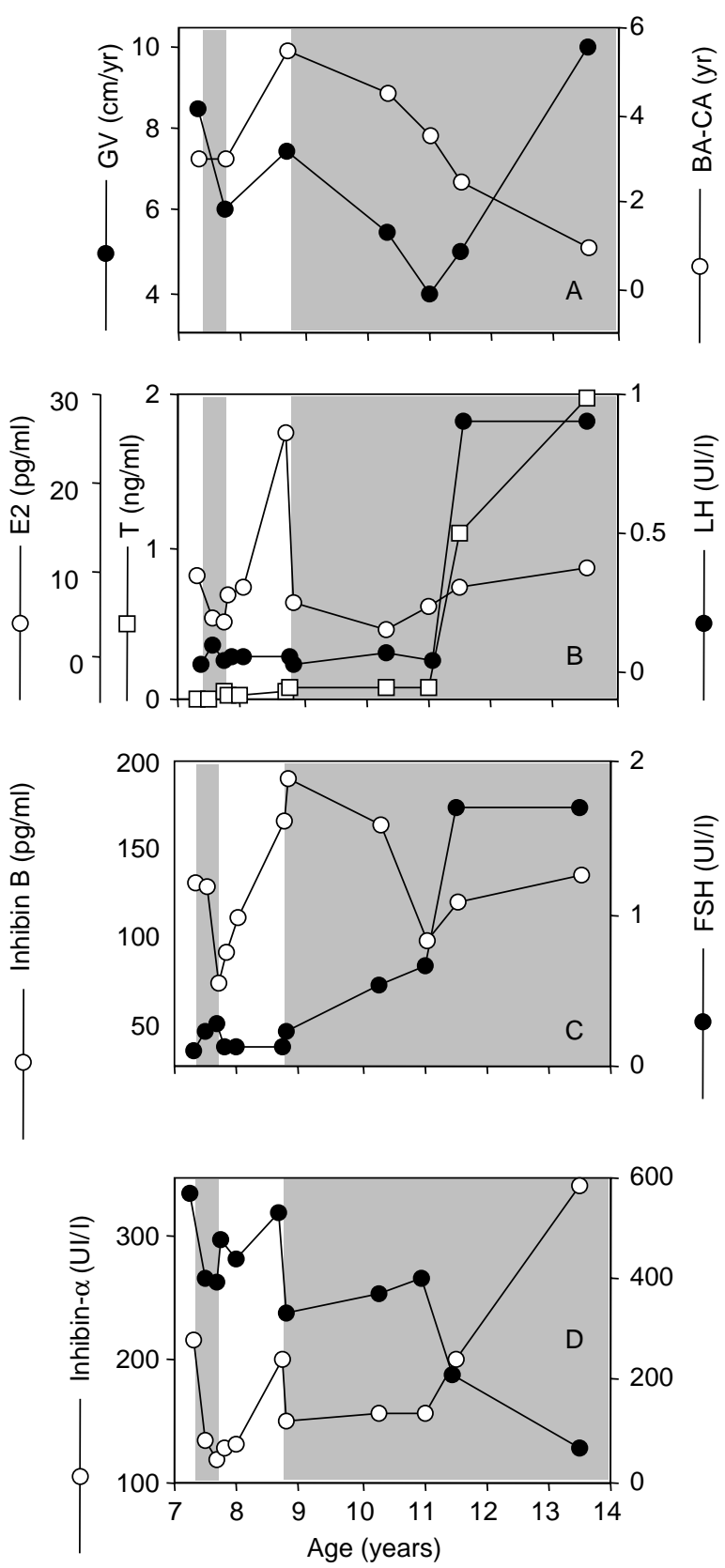

Figure 2 Auxology and hormonal evolution in patient $\mathrm{IV}_{5}$ during treatment with anastrozole. (A) Growth velocity (GV) and difference between bone age and chronological age (BA-CA).

(B) Estradiol (E2), testosterone (T) and luteinizing hormone (LH) levels. (C) Inhibin B and follicle-stimulating hormone (FSH) levels. (D) Inhibin- $\alpha$ and anti-Mullerian hormone (AMH) levels. Shaded areas correspond to anastrozole treatment. an estrogen producing adrenal tumor, showed normal sized adrenal glands. Testicular ultrasound examination revealed bilateral multifocal calcifications of 0.5 to $1 \mathrm{~mm}$ and a testicular size of $2.5 \mathrm{~cm} \times 1.5 \mathrm{~cm}$ bilaterally (Fig. 1). Given the context and the testicular aspect on ultrasound examination, a likely diagnosis of LSCT was made.

Patient $\mathrm{IV}_{4}$, the older brother of patient $\mathrm{IV}_{5}$, was systematically evaluated at 9 years of age. Physical examination revealed melanin spots on the lips and no gynecomastia. Testicular volume was $4 \mathrm{ml}$ bilaterally, with a normal sized penis, and P2 pubic hair development. Height was $143 \mathrm{~cm}(+2.5 \mathrm{SDS})$, growth velocity was $6 \mathrm{~cm} /$ year $(+1 \mathrm{sDS}$ for age) and bone age was 10 years. Similar to his brother, bilateral calcifications (0.8 to $1 \mathrm{~mm}$ ) were observed on testicular ultrasound. Testicular size was $2 \times 1.5 \mathrm{~cm}$ bilaterally.

Patient $\mathrm{III}_{4}$, the father of patients $\mathrm{IV}_{5}$ and $\mathrm{IV}_{4}$, was a 54-year-old man with PJS, with intestinal polyps and characteristic mucosal lesions. His height was $182 \mathrm{~cm}$. He had no history of, or current gynecomastia. Testicular size was $5 \times 3 \mathrm{~cm}$ bilaterally, with no calcifications on ultrasound.

\section{Results}

Direct sequencing of the LKB1 gene showed a mutation at codon 279 in exon 6 , leading to a translational frameshift in all 3 affected family members analyzed. Endocrine investigations in patients $\mathrm{IV}_{5}$ and $\mathrm{IV}_{4}$ (Table 1) showed normal prepubertal serum concentrations of testosterone, estradiol, $\mathrm{AMH}$, inhibin $\mathrm{B}$,

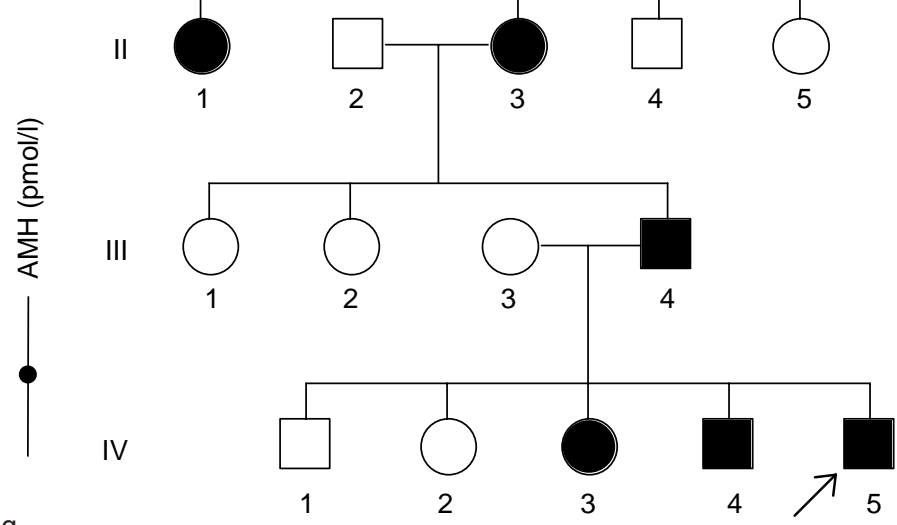

Figure 3 Pedigree of the family with Peutz-Jeghers syndrome and LKB1/STK11 mutation. Shaded symbols correspond to affected family members; the genotype (mutation at codon 279, 6th exon, leading to a translational frameshift) was determined in patients $\mathrm{III}_{4}, \mathrm{IV}_{3}, \mathrm{IV}_{4}, \mathrm{IV}_{5}$; the proband with gynecomastia is indicated by an arrow. 
Table 1 Endocrine evaluation in male relatives with Peutz-Jeghers syndrome.

\begin{tabular}{|c|c|c|c|c|c|}
\hline & $\begin{array}{l}\text { Patient } \mathbf{I V}_{5} \\
\text { (age } 7.3 \mathrm{yr} \text { ) }\end{array}$ & $\begin{array}{c}\text { Patient } \mathbf{I V}_{\mathbf{4}} \\
\text { (age } 9 \mathrm{yr} \text { ) }\end{array}$ & $\begin{array}{l}\text { Normal age-matched } \\
\text { range of values }\end{array}$ & $\begin{array}{l}\text { Patient } \mathrm{III}_{4} \\
\text { (age 54 yr) }\end{array}$ & $\begin{array}{l}\text { Normal age-matched } \\
\text { range of values }\end{array}$ \\
\hline Testosterone $(\mathrm{ng} / \mathrm{ml})^{\mathrm{a}}$ & 0.02 & 0.11 & $0.05-0.3$ & 5.2 & $3-10$ \\
\hline Estradiol $(\mathrm{pg} / \mathrm{ml})^{\mathrm{b}}$ & 9.3 & 6.3 & $<2-17$ & 23.7 & $10-40$ \\
\hline $\mathrm{DHAS}(\mathrm{ng} / \mathrm{ml})^{\mathrm{c}}$ & 238 & 399 & $20-260$ & - & - \\
\hline$\Delta 4(\mathrm{ng} / \mathrm{ml})^{\mathrm{d}}$ & 0.24 & 0.59 & $0.05-0.3$ & - & - \\
\hline FSH (UI/I) & 0.12 & 1 & $0.3-2.5$ & 2.4 & $1-6$ \\
\hline LH (UI/I) & 0.03 & 0.5 & $0.3-1.6$ & 1.8 & $0.8-6$ \\
\hline AMH $(\mathrm{pmol} / \mathrm{l})$ & 570 & 470 & $96-965$ & 47 & $11-84$ \\
\hline Inhibin B (pg/ml) & 130 & 110 & $10-220$ & 178 & $135-150$ \\
\hline Inhibin- $\alpha$ (UI/I) & 215 & 349 & $10-150$ & 219 & $330-710$ \\
\hline
\end{tabular}

${ }^{a-d}$ To convert to SI units multiply by $3.46^{a}, 3.67^{b}, 2.71^{c}, 3.49^{d}$.

DHAS, dehydroepiandrosterone sulfate; $\Delta 4$, Delta4-androstenedione.

FSH and LH. In contrast, plasma inhibin- $\alpha$ concentrations were markedly increased. The father (patient $\mathrm{III}_{4}$ ) had normal hormonal results.

In order to reduce gynecomastia and delay skeletal maturation, patient $\mathrm{IV}_{5}$ was treated with an aromatase inhibitor, anastrozole (Arimidex, Astra-Zeneca), $1 \mathrm{mg}$ orally, once daily, from the age of 7.3 years. Clinical and biological parameters were followed (Fig. 2). During this first treatment period, growth velocity decreased from $9 \mathrm{~cm}$ to $6 \mathrm{~cm} /$ year and gynecomastia from $5 \mathrm{~cm}$ to $3 \mathrm{~cm}$ in diameter. Serum estradiol, inhibin $B$ and inhibin- $\alpha$ declined and gonadotropins did not change. At 4 months on treatment, anastrozole was stopped because of asthenia and severe hot flushes. During the off-treatment period, estradiol and inhibin B concentrations increased and gynecomastia worsened leading to bilateral mastectomy. Eighteen months after anastrozole discontinuation, at age 8.7 years, bone age was 14 years and had therefore advanced by 4 years in 18 months with an adult height prognosis of $165 \mathrm{~cm}$. Anastrozole treatment was resumed and well tolerated. It is still currently used at age 13.7 years with a current height prognosis of $183 \mathrm{~cm}$. Testicular volume increased from the age of 12 years reaching $10 \mathrm{ml}$ at last examination at the age of 13.7 years. Testicular ultrasound was undertaken yearly and showed no change in the size, number or characteristics of the calcifications.

Estradiol levels decreased when treatment was instituted and remained low on treatment. LH did not increase until the age of 11 years while FSH increased progressively from 10 years. Both inhibin B and inhibin- $\alpha$ decreased on treatment and increased at the time of puberty. AMH decreased on treatment and decreased later in puberty, when testosterone levels reached mid-pubertal ranges.

\section{Discussion}

Testicular tumors are extremely rare in prepubertal males and only $5 \%$ of these tumors are of Sertoli cell origin (11). PJS is characterized by an increased risk of gonadal sex cord tumors among other malignancies. Twenty-two patients with PJS and testicular tumors have previously been described (Table 2). Gynecomastia was the presenting symptom in most cases and calcifications varied from minimal to massive. All tumors appeared to be of Sertoli cell origin after biopsy or orchidectomy. Increased estrogen production and aromatase expression in Sertoli cells has been demonstrated in PJS LSCT (12-14). In view of the clinical manifestations of increased estrogen action in patient $\mathrm{IV}_{5}$, one might question why serum estradiol concentrations remained in the normal prepubertal range. This suggests that small amounts of estrogen may be sufficient to induce breast enlargement and promote skeletal maturation. Alternatively, increased bioavailability, local tissular biosynthesis or tissue responsiveness might be involved (15). In this context, it is noteworthy that patient $\mathrm{IV}_{4}$ had similar findings by testicular ultrasonography, only slightly lower estradiol levels but absent gynecomastia and normal skeletal maturation. The frequency of asymptomatic LSCT in PJS remains to be established through prospective familial screening since all but one of the patients with PJS and LSCT reported to date presented with gynecomastia.

The Sertoli cell origin of LSCT prompted us to measure plasma inhibins and AMH. Inhibin B is usually the main form of inhibin found in the male circulation and is involved in the regulation of FSH secretion. It is a dimer of disulfide-linked $\alpha$ and $\beta$-B subunits, primarily secreted by Sertoli cells (16). The $\alpha$ subunit is predominantly expressed in Sertoli cells but also in Leydig cells (17). In our two patients, inhibin $B$ levels were at the upper normal range of prepubertal boy values, while inhibin- $\alpha$ levels were markedly elevated. Few studies have examined inhibin subunits in human testicular tumors, but they appear to be a marker of Sertoli cell tumors (18). Mechanisms for the discordance between $\alpha$ and $\beta$-B subunit levels are poorly known and our observation suggests that such dissociation can occur in tumoral Sertoli cells in 
Table 2 Summary of the published literature on LSCT in boys with PJS.

\begin{tabular}{|c|c|c|c|c|c|c|}
\hline Reference & $\begin{array}{c}\text { Age at diagnosis } \\
(y r)\end{array}$ & $\begin{array}{c}\text { Gynecomastia } \\
(\mathrm{Y} / \mathrm{N})\end{array}$ & $\begin{array}{l}\text { Plasma estradiol } \\
(\mathrm{pg} / \mathrm{ml})^{\mathrm{a}}\end{array}$ & $\begin{array}{l}\text { Testicular calcifications } \\
\text { on ultrasound }\end{array}$ & Testicular management & $\begin{array}{l}\text { Management of } \\
\text { gynecomastia }\end{array}$ \\
\hline 23 & 1.6 & Y & 27 & Bilateral & Bilateral orchidectomy & NA \\
\hline 5 & 3 & Y & 47 & Unilateral & Unilateral orchidectomy & NA \\
\hline 24 & 3 & Y & 30 & Bilateral & NA & Mastectomy \\
\hline 13 & 3.5 & $\mathrm{Y}$ & 98 & Bilateral & Bilateral orchidectomy & Mastectomy \\
\hline 14 & 3.5 & Y & 97 & NA & Bilateral orchidectomy & NA \\
\hline 25 & 4 & Y & NA & Bilateral & Follow-up & NA \\
\hline 12 & 4.5 & $\mathrm{Y}$ & 39 & Bilateral & NA & Testolactone, mastectomy \\
\hline 13 & 5.5 & Y & 45 & Bilateral & Bilateral orchidectomy & Mastectomy \\
\hline 26 & 5.5 & $\mathrm{Y}$ & 23 & Bilateral & Loss of follow-up & NA \\
\hline 27 & 6 & Y & High & Absent & Unilateral orchidectomy & NA \\
\hline 28 & 6 & Y & 27 & Absent & Bilateral orchidectomy & NA \\
\hline 14 & 7 & Y & 25 & NA & Bilateral orchidectomy & Mastectomy \\
\hline 29 & 7 & Y & $<2$ & Bilateral & NA & Bilateral mastectomy \\
\hline 20 & 7.5 & $\mathrm{Y}$ & $<2$ & Bilateral & NA & Testolactone \\
\hline 14 & 8 & Y & 5 & NA & NA & Mastectomy \\
\hline 30 & 8 & Y & NA & Bilateral & Bilateral orchidectomy & NA \\
\hline 31 & 8 & Y & NA & Bilateral & Follow-up & NA \\
\hline 31 & 8.5 & $\mathrm{Y}$ & - & Bilateral & Follow-up & NA \\
\hline 32 & 11 & $\mathrm{~N}$ & NA & Bilateral & Bilateral orchidectomy & NA \\
\hline 31 & 11 & $\mathrm{Y}$ & NA & Bilateral & Follow-up & NA \\
\hline 33 & 13 & Y & Normal & Bilateral & Bilateral orchidectomy & NA \\
\hline 31 & 14 & Y & NA & Bilateral & Follow-up & NA \\
\hline
\end{tabular}

${ }^{a}$ Normal prepubertal values: $5-17 \mathrm{pg} / \mathrm{ml}$. To convert to SI units multiply by 3.67 . NA, information not available. 
LSCT. We propose that serum inhibin- $\alpha$ subunit is a marker of Sertoli cell testicular tumors (and in particular LSCT) in prepubertal boys.

The management of LSCT and the evaluation of its malignant potential is an important part of the discussion. In at least 9 of 22 reported patients (Table 2) a bilateral orchidectomy was performed (14). We decided on a conservative medical treatment on account of the low risk of malignant transformation of sex cord tumors (2), taking the option of a careful follow-up, allowing sperm preservation if an orchidectomy was decided upon after sexual maturation. Therefore, medical treatment was warranted to reduce the effects of increased estrogens on the breast and skeleton. Aromatase inhibitors are currently the best option to achieve this goal (19) and testolactone has been used previously $(12,20)$. We used anastrozole, an effective third generation inhibitor of estrogen synthesis. Interestingly, initiation of the treatment was associated with 'menopausal-like symptoms', as observed with gonadotropin-releasing hormone agonists. Symptoms might have been amplified by the psychological distress of the family with several severely affected members. Overall, anastrozole was clinically efficient and decreased breast development and growth velocity and delayed bone maturation. Serum estradiol concentrations decreased, but LH and testosterone did not increase, as opposed to the observations made with aromatase inhibitors in early pubertal boys (21). The decrease in inhibin B, inhibin- $\alpha$ and AMH levels on treatment was unexpected since these markers are believed to reflect Sertoli cell activation by the mutated STK11 serine/threonine kinase. Our observation suggests that increased estrogen production might be a primary event, regulating downstream production of Sertoli cell peptides. A further argument for the role of estrogen signaling in Sertoli cell tumorigenesis comes from observations made in male mice with inhibin- $\alpha$ knockout mice who develop Sertoli cell tumors that are prevented by estrogen receptor $\alpha$ and $\beta$ knockouts (22).

In conclusion, LSCT, revealed by testicular calcifications, can occur in prepubertal boys with PJS in the absence of gynecomastia. Inhibin- $\alpha$ seems to be an interesting marker for these tumors. Anastrozole is efficient in controlling the clinical manifestations of LSCT and should be proposed as an alternative to orchidectomy, which is often performed in this condition.

\section{References}

1 Jeghers H, McKusick J \& Katz KH. Generalized intestinal polyposis and melanin spots on oral mucosa, lips and digits: syndrome of diagnostic significance. New England Journal of Medicine 1949 241 1031-1036.

2 Giardiello FM, Welsh SB, Hamilton SR, Offerhaus GJ, Gittelsohn AM, Booker SV, Krush AJ, Yardley JH \& Luk GD. Increased risk of cancer in the Peutz-Jeghers syndrome. New England Journal of Medicine 1987316 1511-1514.

3 Hemminki A, Tomlinson I, Markie D, Jarvinen H, Sistonen P. Bjorkqvist AM, Knuutila S, Salovaara R, Bodmer W, Shibata D, de la Chapelle A \& Aaltonen LA. Localization of a susceptibility locus for Peutz-Jeghers syndrome to $19 \mathrm{p}$ using comparative genomic hybridization and targeted linkage analysis. Nature Genetics $19971587-90$.

4 Proppe KH \& Scully RE. Large-cell calcifying Sertoli cell tumor of the testis. American Journal of Clinical Pathology 1980 74 607-619.

5 Dubois RS, Hoffman WH, Krishnan TH, Rising JA, Tolia VK, Sy DA \& Chang CH. Feminizing sex cord tumor with annular tubules in a boy with Peutz-Jeghers syndrome. Journal of Pediatrics 1982 $101568-571$.

6 Lahlou N, Fennoy I, Carel JC \& Roger M. Inhibin B and anti-Mullerian hormone, but not testosterone levels, are normal in infants with nonmosaic Klinefelter syndrome. Journal of Clinical Endocrinology and Metabolism 200489 1864-1868.

7 Lahlou N, Chabbert-Buffet N, Christin-Maitre S, Le Nestour E, Roger M \& Bouchard P. Main inhibitor of follicle stimulating hormone in the luteal-follicular transition: inhibin A, oestradiol, or inhibin B? Human Reproduction 199914 1190-1193.

8 Lahlou N, Le Nestour E, Chanson P, Seret-Begue D, Bouchard P, Roger M \& Warnet A. Inhibin and follicle-stimulating hormone levels in gonadotroph adenomas: evidence of a positive correlation with tumour volume in men. Clinical Endocrinology 1993 38 301-309.

9 Amos CI, Keitheri-Cheteri MB, Sabripour M, Wei C, McGarrity TJ, Seldin MF, Nations L, Lynch PM, Fidder HH, Friedman E \& Frazier ML. Genotype-phenotype correlations in Peutz-Jeghers syndrome. Journal of Medical Genetics 200441 327-333.

10 Greulich WW \& Pyle SI. Radiographic Atlas of Skeletal Development of the Hand and Wrist. Stanford, CA: Stanford University Press, 1959.

11 Weitzner S \& Gropp A. Sertoli cell tumor of testis in childhood. American Journal of Diseases in Childhood 1974128 541-543.

12 Coen P, Kulin H, Ballantine T, Zaino R, Frauenhoffer E, Boal D, Inkster S, Brodie A \& Santen R. An aromatase-producing sex-cord tumor resulting in prepubertal gynecomastia. New England Journal of Medicine 1991324 317-322.

13 Young S, Gooneratne S, Straus FH 2nd, Zeller WP, Bulun SE \& Rosenthal IM. Feminizing Sertoli cell tumors in boys with PeutzJeghers syndrome. American Journal of Surgery and Pathology $19951950-58$.

14 Bulun SE, Rosenthal IM, Brodie AM, Inkster SE, Zeller WP, DiGeorge AM, Frasier SD, Kilgore MW \& Simpson ER. Use of tissue-specific promoters in the regulation of aromatase cytochrome P450 gene expression in human testicular and ovarian sex cord tumors, as well as in normal fetal and adult gonads. Journal of Clinical Endocrinology and Metabolism 199377 1616-1621.

15 Miller WR, Mullen P, Sourdaine P, Watson C, Dixon JM \& Telford J. Regulation of aromatase activity within the breast. Journal of Steroid Biochemistry and Molecular Biology 199761 193-202.

16 Risbridger GP, Schmitt JF \& Robertson DM. Activins and inhibins in endocrine and other tumors. Endocrine Reviews 200122 $836-858$.

17 Bergh A \& Cajander S. Immunohistochemical localization of inhibinalpha in the testes of normal men and in men with testicular disorders. International Journal of Andrology 199013 463-469.

18 Toppari J, Kaipia A, Kaleva M, Laato M, de Kretser DM, Krummen LA, Mather JP \& Salmi TT. Inhibin gene expression in a large cell calcifying Sertoli cell tumour and serum inhibin and activin levels. APMIS 1998106 101-112.

19 Wickman S, Sipila I, Ankarberg-Lindgren C, Norjavaara E \& Dunkel L. A specific aromatase inhibitor and potential increase in adult height in boys with delayed puberty: a randomised controlled trial. Lancet $20013571743-1748$.

20 Alikasifoglu A, Gonc EN, Akcoren Z, Kale G, Ciftci AO, Senocak ME \& Yordam N. Feminizing Sertoli cell tumor associated with PeutzJeghers syndrome. Journal of Pediatric Endocrinology and Metabolism $200215449-452$.

21 Wickman S \& Dunkel L. Inhibition of P450 aromatase enhances gonadotropin secretion in early and midpubertal boys: evidence 
for a pituitary site of action of endogenous E. Journal of Clinical Endocrinology and Metabolism 200186 4887-4894.

22 Burns KH, Agno JE, Chen L, Haupt B, Ogbonna SC, Korach KS \& Matzuk MM. Sexually dimorphic roles of steroid hormone receptor signaling in gonadal tumorigenesis. Molecular Endocrinology $2003172039-2052$.

23 Niewenhuis JC, Wolf MC \& Kass EJ. Bilateral asynchronous Sertoli cell tumor in a boy with the Peutz-Jeghers syndrome. Journal of Urology 1994152 1246-1248.

24 Hertl MC, Wiebel J, Schafer H, Willig HP \& Lambrecht W. Feminizing Sertoli cell tumors associated with Peutz-Jeghers syndrome: an increasingly recognized cause of prepubertal gynecomastia. Plastic Reconstruction and Surgery 1998102 1151-1157.

25 Mulet Ferragut JF, Femenia A, Morlans J, Bregante J, Herrera M \& Rossell A. Gynecomastia and testicular tumor in children with Peutz-Jeghers syndrome. Circulation in Pediatrics 200215 82-83.

26 Wilson DM, Pitts WC, Hintz RL \& Rosenfeld RG. Testicular tumors with Peutz-Jeghers syndrome. Cancer 198657 2238-2240.

27 Cantu JM, Rivera H, Ocampo-Campos R, Bedolla N, CortesGallegos V, Gonzalez-Mendoza A, Diaz M \& Hernandez A. PeutzJeghers syndrome with feminizing Sertoli cell tumor. Cancer $198046223-228$

28 Ros P, Nistal M, Alonso M, Calvo de Mora J, Yturriaga R \& Barrio R. Sertoli cell tumour in a boy with Peutz-Jeghers syndrome. Histopathology $1999 \mathbf{3 4} 84-86$.
29 Bergada I, Del Toro K, Katz O, Chemes H \& Campo S. Serum inhibin B concentration in a prepubertal boy with gynecomastia and Peutz-Jeghers syndrome. Journal of Pediatric Endocrinology and Metabolism 200013 101-103.

30 Ceccamea A, Cozzi F, Farragiana T, Boscherini B \& Pierro A. Feminizing Sertoli cell tumor associated with Peutz-Jeghers syndrome (histologic and ultrastructural study). Tumori 198571 379-385.

31 Venara M, Rey R, Bergada I, Mendilaharzu H, Campo S \& Chemes H. Sertoli cell proliferations of the infantile testis: an intratubular form of Sertoli cell tumor? American Journal of Surgical Pathology 200125 1237-1244.

32 Chang B, Borer JG, Tan PE \& Diamond DA. Large-cell calcifying Sertoli cell tumor of the testis: case report and review of the literature. Urology 199852 520-522; discussion 522-523.

33 Dreyer L, Jacyk WK \& du Plessis DJ. Bilateral large-cell calcifying Sertoli cell tumor of the testes with Peutz-Jeghers syndrome: a case report. Pediatric Dermatology 199411 335-337.

Received 18 August 2005

Accepted 28 October 2005 